\title{
A HYBRID APPROACH BASED ON ANP AND GREY RELATIONAL ANALYSIS FOR MACHINE SELECTION
}

\author{
Mehmet Kabak, Metin Dağdeviren
}

Original scientific paper

In a manufacturing system, inappropriate machine selection may lead to many problems by negatively affecting productivity, precision, flexibility and product quality, and machine selection is considered to be an important subject to make the system effective. A Multi-Criteria Decision Making (MCDM) which is relying on the different criteria and alternatives is to choose the most suitable machine among many alternatives. In this study, for machine selection problem, a hybrid approach is proposed which combines Analytic Network Process (ANP) and Grey Relational Analysis (GRA). To identify weights of the selection criteria and to analyze the machine selection problem, the ANP is used whilst the GRA is used for ranking. The proposed approach can be applied easily by anybody (technical staff, managers, manufacturer, vendor, etc.) familiar with basic Microsoft Excel knowledge. The proposed approach is used for the selection problem of $\mathrm{CNC}$ router machines to be bought by an international company. As a result, the company has considered the method and outcomes acceptable and appropriate to implement to the machine selection decisions.

Keywords: Analytic Network Process (ANP); CNC router machine; Grey Relational Analysis (GRA); Machine selection; Multi Criteria Decision-Making $(M C D M)$

\section{Hibridni pristup zasnovan na analitičkom mrežnom postupku i sivoj relacijskoj analizi za izbor stroja}

Izvorni znanstveni članak

U proizvodnom sustavu, neodgovarajući izbor stroja može stvoriti mnoge probleme jer može negativno utjecati na proizvodnost, preciznost, fleksibilnost i kvalitetu proizvoda, pa se odabir stroja smatra važnim za učinkovitost sustava. Odlučivanje na temelju višestrukih kriterija - MCDM (Multi-Criteria Decision Making) koje se zasniva na različitim kriterijima i alternativama znači izabrati najpogodniji stroj između mnogih alternativa. U ovom radu o problemu izbora stroja, predlaže se hibridni pristup koji kombinira analitički mrežni postupak - ANP (Analytic Network Process) i postupak sive relacijske analize - GRA (Grey Relational Analysis). Za prepoznavanje težina izbornih kriterija i analizu problema izbora stroja primijenjen je ANP dok je GRA primijenjen za rangiranje. Svatko s osnovnim poznavanjem Microsoft Excel-a (tehničko osoblje, menađeri, proizvođač, prodavač itd.) može lako primijeniti predloženi pristup. Taj je pristup primijenjen kod problema izbora strojeva sa CNC usmjernikom koje bi kupila internacionalna kompanija. Kao rezultat, kompanija je razmotrila tu metodu i ishode prihvatljive i odgovarajuće za primjenu kod donošenja odluke o izboru stroja

Ključne riječi: analitički mrežni postupak; izbor stroja; odlučivanje na temelju višestrukih kriterija; siva relacijska analiza; stroj s CNC usmjernikom

\section{Introduction}

Selection of a proper machine or equipment is a very important activity for manufacturing systems due to the fact that the overall performance and productivity may be influenced negatively by improperness of selected machine or equipment. The output of a manufacturing system (i.e. the rate, quality and cost) mostly depends on what kinds of machines are selected and then implemented [1]. In addition, one of the major effects on a company's global competitive power is machine or equipment selection. To use correct machines may increase the efficiency of production process and effectiveness of manpower and improve the flexibility of the system used. The importance of machine selection cannot be disregarded. Nevertheless, in terms of availability of different types and brands in the market today, to identify the most suitable machine for any given scenario is not a simple task [2].

Decision making process of buying a new machine is time consuming and difficult and also requires knowledge and experience in the business. Thus, the process can be a hard task for technical staff (including engineers) and managers, and also for the machine manufacturer or vendor, to carry out. To have correct and effective assessment, the decision makers (DMs) may need to take into consideration a vast amount of data and factors [1].

In spite of an important role of machine selection in the establishment of effective production system, there are limited publications on the subject [3]. The selection process studies may be split into two groups; the selection of the equipment and the selection of the machine. For flexible manufacturing systems (FMS) "multi-attribute utility theory (MAUT)" which is using AHP (Analytic Hierarchy Process) to quantify the contribution of different structural and infrastructural factors has been developed as a decision support system to be applied on multi-criteria machine selection problems [4]. In order to evaluate the quality of the heuristic solution, lower bounds are required and they are generated by Lagrangian relaxation. For the problem, the genetic algorithm is also applied to make multi-objective optimization for optimum tolerance synthesis [5]. A fuzzy multi-attribute decision making (MADM) model was introduced to support the DMs for machine selection of FMS [6]. The cell formation and the machine selection problems are alternative models to design a new cellular manufacturing system having a heuristic algorithm [7]. Unweighted and weighted multi-attribute axiomatic design (AD) including crisp and fuzzy criteria is used to develop fuzzy multiattribute equipment selection [3]. AHP and TOPSIS methods were used together to select the sector for ERP implementation to achieve the best effect on supply chain performance [8]. Fuzzy models [1] and hybrid approaches $[9,10]$ can be seen in recent studies made for decision making problems. An integrated fuzzy multi-criteria decision making methodology utilized from fuzzy sets, ANP and PROMETHEE approaches are also used for material handling equipment selection [11]. ANP is applied to projects prioritization at higher education institution, as the studies for equipment replacement problems are introduced [12]. 
Many different and conflicting criteria must be taken into account to rank a number of alternatives for machine selection problem which is accepted as a multi-criteria decision-making (MCDM) problem. Even though there are several different methods as MCDM, none of them can be considered better than others. However, some are much more suitable for specific problems [13, 14]. The most popular ones are PROMETHEE, scoring models, AHP, ANP and GRA, axiomatic design (AD), utility models, TOPSIS and ELECTRE [15, 16]. Prior to the selection of suitable method for the problem, all elements of MCDM should be developed. The MCDM method had better not be applied until the problem, possible alternatives, different outcomes, conflicts between the criteria and data uncertainty level have been identified correctly.

In the literature, MCDM methods such as AHP and Fuzzy AHP, are used for machine selection problems, making the evaluations in a hierarchical structure. Those methods assume that elements between layers and among elements of layers are independent of each other. On the other hand, in this study, criteria are weighted by ANP in which dependence and feedback within a set of elements (inner dependence) and among different sets of elements (outer dependence) can also be included. Then alternative machines are ranked by GRA. Because the fuzzy set theory of Zadeh develops membership functions for the interval of fuzzy real numbers ranging from 0 to 1 and subjectively measures degrees of closeness for the specific attributes or alternatives, while the grey theory collects or specifies the range of values for the specific attributes or alternatives based on the incomplete information and then initializes the values into grey real numbers with the base value of $1[17,18]$. Whereas the measurement of grey numbers depends on the collection of existing data, fuzzy numbers' needs sufficient expert knowledge. The grey system theory can generate satisfactory outcomes using a relatively small amount of data or with great variability in factors [19].

In this study, a model integrating ANP and GRA is proposed for machine selection problem. The ANP method is applied to analyse the structure of the problem and assign weights to the criteria, and the GRA method is used to rank the alternatives. The machine selection problem is discussed in the introduction. The rest of this article is structured as follows: In Section 2, a brief overview of ANP and GRA is given. The proposed ANPGRA hybrid approach for machine selection is presented and the detailed stages and steps of the proposed approach are determined, the application for the company is detailed in Section 3. Finally, conclusions and future research directions are discussed in Section 4.

\section{Principles of ANP and GRA methods \\ 2.1 The ANP method}

The ANP is a practical MCDM method introduced by Saaty and is used to calculate weights/priorities. The ANP method has major advantages: (a) Criteria weights are calculated by pairwise comparison of DMs by using 9 point scale as shown in table 1; (b) Quantitative and qualitative values can be used in a pairwise comparison; (c) ANP does not require special knowledge and can be simply applied; (d) ANP allows individual or group decision making process; (e) The effects of feedback and interdependence among criteria are included in calculations [20, 21]. In this study, the ANP approach is preferred to determine criteria weights based on these advantages.

The ANP is capable of handling interdependence between the decision levels and attributes by obtaining the composite weights through the development of a "supermatrix". The supermatrix is actually a partitioned matrix, where each matrix segment represents a relationship between two components or clusters in a system [20]. The detailed methodology of ANP can be found in various published papers and "Super Decisions" software can be used to calculate the criteria's weights. However, matrix operations can be used to calculate the weights of criteria especially where the numbers of criteria/elements in the model are relatively few. This approach makes readers to understand the method in detail. In this paper, Microsoft Excel is used and calculations are done step by step.

Table 1 Nine-point intensity of importance scale

\begin{tabular}{|c|l|}
\hline Intensity of importance & \multicolumn{1}{c|}{ Definition } \\
\hline 1 & Equal importance \\
\hline 3 & Moderate importance \\
\hline 5 & Strong importance \\
\hline 7 & Very strong importance \\
\hline 9 & Absolute importance \\
\hline $2,4,6,8$ & Intermediate values \\
\hline
\end{tabular}

There are many studies in current literature using ANP to solve decision making problems. ANP has been used to perform logistics and supply chain management analysis [22] and to evaluate alternative research-development projects [23]. It is also used in the inter-dependent information system project selection process, the quality function deployment process, the project selection problem, personnel selection and for location selection $[24 \div 28]$. ANP is used for BOCR analysis, determination of faulty behaviour risks in work and determination of building's energy performance [29, 30]. The method is also used for the selection of dispatching rules in an organization and selection of milling machines [9, 31].

\subsection{The GRA method}

The grey system theory developed by Denghas been comprehensively applied in various industrial fields, including environmental system decision making, supplier selection, market forecasting and portfolio selection, evaluating credit ability and product development in recent years $[17,32 \div 36$ ). It has been proven to be beneficial for DMs with the imprecise and incomplete information in a lot of studies. GRA is one of the most important application areas of grey system theory. The similarity to the ideal solution is measured for each option in this method. The option with the greatest similarity is most preferred one. However, relations between multiple performance criteria can be resolved by optimizing grey relational grades (GRG) $[37 \div 39]$. In our study, the GRA is used to build an evaluation method to determine the best machine for a particular company. The GRA is 
calculated as follows [40]:

\section{1) Calculate the GRG}

Let $X_{0}$ be the referential series with $k$ entities/criteria of $X_{1}, X_{2}, \ldots, X_{i}, \ldots, X_{N}$. Then

$$
\begin{aligned}
& X_{0}=\left\{x_{0}(1), x_{0}(2), \ldots, x_{0}(j), \ldots, x_{0}(k)\right\} \\
& X_{1}=\left\{x_{1}(1), x_{1}(2), \ldots, x_{1}(j), \ldots, x_{1}(k)\right\} \\
& \vdots \\
& X_{i}=\left\{x_{i}(1), x_{i}(2), \ldots, x_{i}(j), \ldots, x_{i}(k)\right\} \\
& \vdots \\
& X_{N}=\left\{x_{N}(1), x_{N}(2), \ldots, x_{N}(j), \ldots, x_{N}(k)\right\}
\end{aligned}
$$

The grey relational coefficient (GRC) between the compared series $X_{i}$ and the referential series of $X_{0}$ at the $j^{\text {th }}$ criterion is determined as:

$$
\gamma_{0 i}(j)=\frac{\Delta \min +\zeta \Delta \max }{\Delta_{0 i}(j)+\zeta \Delta \max }
$$

where $\Delta_{0 i}(j)$ means the absolute value of difference between $X_{0}$ and $X_{i}$ at the $\mathrm{j}$-th criterion, that is $\Delta_{0 i}(j)=\left|x_{0}(j)-x_{i}(j)\right|, \quad$ and $\quad \Delta \max =\max _{i} \max _{j} \Delta_{0 i}(j)_{0}$, $\Delta \min =\min _{i} \min _{j} \Delta_{0 i}(j)_{0} . \zeta$ is the distinguishing coefficient that is stated in the range $0 \leq \zeta \leq 1$ and typically $\zeta=0,5$.

Then, the GRG for a series of $X_{i}$ is derived as

$$
\Gamma_{o i}=\sum_{j=1}^{K} w_{j} \gamma_{o i}(j)
$$

where $w_{j}$ is the weight of the $j^{\text {th }}$ criterion. If the weight is not applied, get $w_{j}=1 / K$.

\section{2) Data normalization}

The situation in which the data are not pre-processed to a comparative range directs the ignorance of the small data to calculate the relational coefficient in Eq. (2). First, the data series are normalized and then the GRCs are calculated to ensure that all of them are in the same order. The three different formulas as shown below and the linearity of data normalization are used not to misapply the normalized data [41]. They are:

a) Upper-bound effectiveness measuring (i.e., the bigger the better)

$$
X_{i}^{*}(j)=\frac{X_{i}(j)-\min _{j} X_{i}(j)}{\max _{j} X_{i}(j)-\min _{j} X_{i}(j)},
$$

b) Lower-bound effectiveness measuring (i.e., the smaller the better)

$$
X_{i}^{*}(j)=\frac{\max _{j} X_{i}(j)-X_{i}(j)}{\max _{j} X_{i}(j)-\min _{j} X_{i}(j)},
$$

c) Moderate effectiveness measuring (i.e., nominal the best). If $\min _{j} x_{i}(j) \leq x_{o b}(j) \leq \max _{j} x_{i}(j)$, then

$X_{i}^{*}(j)=\frac{\left|X_{i}(j)-X_{o b}(j)\right|}{\max _{j} X_{i}(j)-\min _{j} X_{i}(j)}$,

if $\max _{j} x_{i}(j) \leq x_{o b}(j)$,

then $\quad X_{i}^{*}(j)=\frac{x_{i}(j)-\min _{j} X_{i}(j)}{X_{o b}(j)-\min _{j} X_{i}(j)}$ or

if $x_{o b}(j) \leq \min _{j} x_{i}(j)$,

then $\quad X_{i}^{*}(j)=\frac{\max _{j} X_{i}(j)-x_{i}(j)}{\max _{j} X_{i}(j)-X_{o b}(j)}$

where $X_{o b}(j)$ is the objective value of the criterion $j$.

\section{The proposed ANP-GRA integrated approach}

The proposed approach as shown in Fig. 1 consists of four stages and 12 steps. In the first stage, following the forming of the decision making team (DMT), alternatives and criteria are determined, decision hierarchy is structured and approved with consensus by this team. The criteria used for evaluating machines are derived from the literature and experts' opinions. The network structure is formed and the criteria weights are calculated by using the ANP method in the second stage. The scale given in table 1 is used for pairwise comparisons. The details of the calculation are explained in the section 3 . The criteria weights are used as coefficients of the GRA model in the third stage. However, the data set is normalized, GRCs and GRDs are calculated at this stage. Excel is the software used to calculate the mathematical analysis and obtain the results. Finally, weighted and unweighted ranks for alternative machines are determined. The proposed approach is presented schematically in Fig. 1.

A manufacturing company located in Ankara, Turkey would like to purchase several router machines (RM) to reduce the work-in-process inventory and to replace its old machines. These complex machines make meaningful improvements in the manufacturing processes of the firm and the correct decisions made at this stage can bring the company a competitive advantage. The experts from the company can easily identify alternatives but it is not easy to select the most suitable one among alternatives which are superior to each other according to the different specifications. Therefore, a scientific method is required and the proposed approach will be used for the selection problem. 


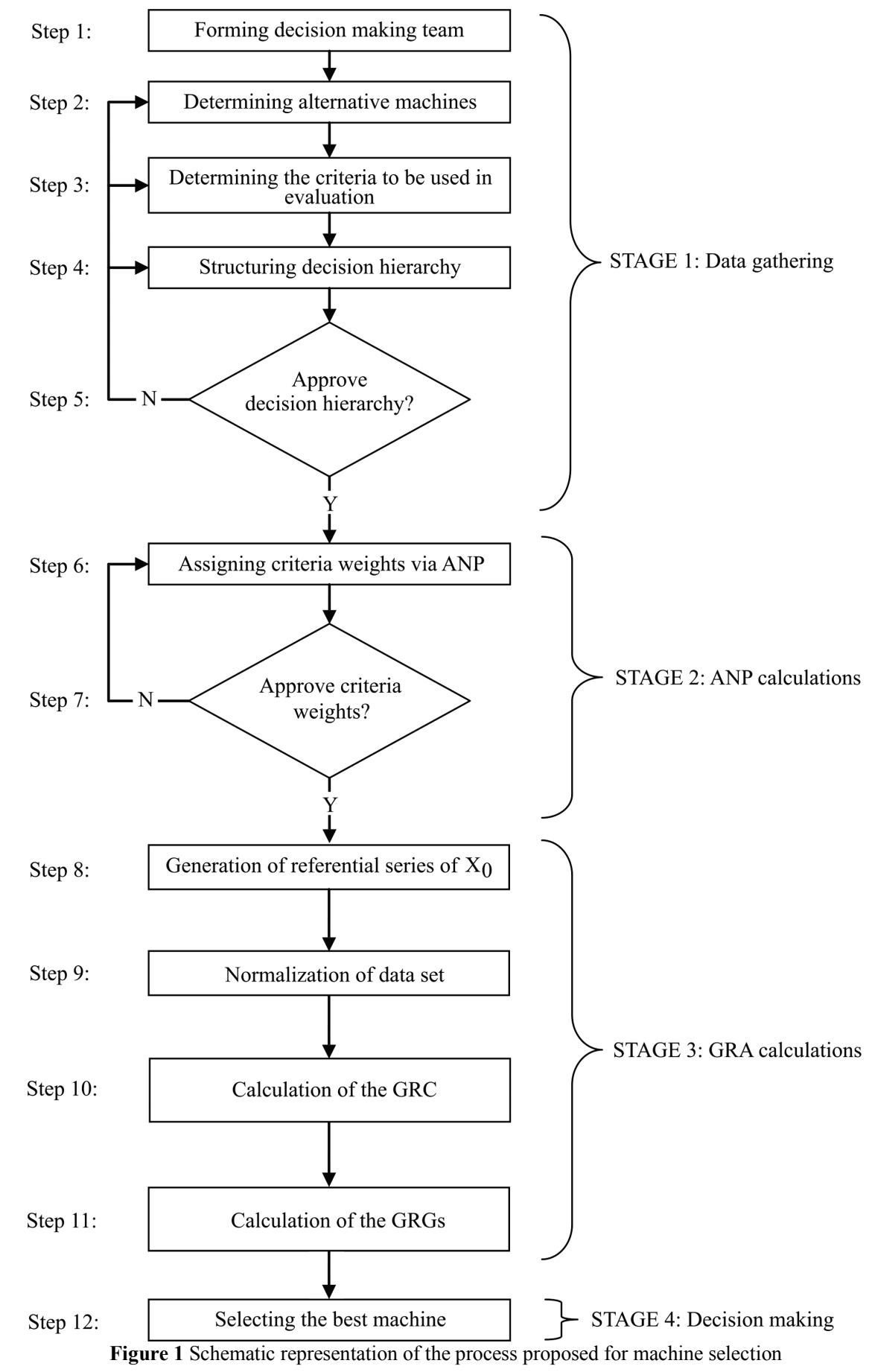

\subsection{Data gathering}

In the application, the DMT consisting of five people who will take part in the machine selection process is formed. Three members of the DMT are experts from the company and the remaining two members are academics who have published machine or equipment selection papers and worked in different universities. With preliminary work, the DMT determined four router machines appropriate for the needs of the company. The four criteria, namely cost [42], quality [43], flexibility [44], performance [45] and fourteen sub-criteria are determined by the DMT via literature review and shown in Tab. 2. The network for the machine selection problem is detailed in Fig. 2.
Table 2 Criteria of proposed model for machine selection

\begin{tabular}{|c|l|c|}
\hline \multicolumn{1}{|c|}{ Criteria } & \multicolumn{1}{|c|}{ Sub-criteria } & Abb. \\
\hline \multirow{4}{*}{ Cost $(C)$} & Capital cost & $C C$ \\
\cline { 2 - 3 } & Operation cost & $O C$ \\
\cline { 2 - 3 } & Maintenance cost & $M C$ \\
\cline { 2 - 3 } & Depreciation & $D$ \\
\hline \multirow{4}{*}{ Quality $(Q)$} & Scrap \& Rework & $S R$ \\
\cline { 2 - 3 } & Reliability & $R$ \\
\cline { 2 - 3 } & Product conformance & $P C$ \\
\hline \multirow{4}{*}{ Performance $(P)$} & Flexibility in mass production & $F M P$ \\
\cline { 2 - 3 } & Variety and flexibility of products & $V F P$ \\
\cline { 2 - 3 } & Safety & $S C A$ \\
\cline { 2 - 3 } & System control and automation & $S C$ \\
\cline { 2 - 3 } & Utilization time & $U$ \\
\cline { 2 - 3 } & Manufacturing rate & $M R$ \\
\hline
\end{tabular}


The decision hierarchy of the problem consists of four levels. The main goal of the decision process which is determined as "the selection of the best machine" is in the first level of the hierarchy. The main criteria/factors are on the second level, the sub-criteria are on the third level and alternative RMs are on the fourth level. The criteria of second level are explicitly linked to the goal with a one-way arrow. These one-way arrows mean the goal is affected by the criteria. The arrows in the second level show the inter-dependence among the criteria. The innerdependencies among the criteria show their effects to each other. The one-way arrow between flexibility and quality factors means flexibility factor is affected by quality factor; two-way arrow means factors affect each other. These relations must be analysed to calculate the final criteria weights. Sub-criteria related to the criteria are in the third level of the model. As a result of the ranking alternatives via GRA, alternatives are not connected to the criteria or the goal.

\subsection{ANP calculations}

Criteria weights are calculated by using ANP after the network structure of the machine selection problem is confirmed. The pairwise comparison matrixes are formed depending on the relations between the criteria and DMT members individually evaluated them using the "1 to 9 scale". Geometric means of the individual evaluations are calculated and it is asked for consensus to the members. Details are explained below.

Step 1: Local and global weights of the criteria and sub-criteria whose effects are shown in Fig. 2 are calculated. By using "Super Decision" software, comparison matrices can be formed and weights of criteria can be calculated as shown in Fig. 3. However, in this study, all the calculations will be conducted using Microsoft Excel in order to explain the ANP in detail. DMT evaluate one by one pair-wise comparisons by using the Saaty's 1 to 9 scale (Tab. 1). For example, cost criteria are compared with quality criteria using the question "Which is considered more important by the DMT selecting the machine, and how much more important is it with respect to satisfaction with the machine?" The evaluation process is the same for the other pairwise comparisons. The weights of criteria calculated by the software as shown in Fig. 3 and calculated by using Microsoft Excel as shown in Tab. 3 are the same. Tabs. $3 \div 7$ show criteria's pairwise comparisons, weights and consistency indexes. If the value of Consistency Ratio $(C R)$ for the matrix is smaller than $10 \%$, the DMs' consistency for the evaluations within the matrix is acceptable. If the $C R$ is equal to or greater than $10 \%$, pairwise comparisons within the matrix must be evaluated again.

Table 3 Local weights and pairwise comparison matrix of criteria

\begin{tabular}{|c|c|c|c|c|c|}
\hline Criteria & $C$ & $Q$ & $F$ & $P$ & Weights \\
\hline$C$ & 1,00 & 0,46 & 0,56 & 0,39 & 0,128 \\
\hline$Q$ & 2,19 & 1,00 & 3,43 & 1,42 & 0,395 \\
\hline$F$ & 1,79 & 0,29 & 1,00 & 0,34 & 0,147 \\
\hline$P$ & 2,57 & 0,70 & 2,97 & 1,00 & 0,33 \\
\hline
\end{tabular}

$C R=0,044$
Table 4 Local weights and pairwise comparison matrix of cost sub-

\begin{tabular}{|c|c|c|c|c|c|}
\hline$C$ sub-criteria & $C C$ & $O C$ & $M C$ & $D$ & Weights \\
\hline$C C$ & 1,00 & 0,63 & 0,90 & 2,17 & 0,23 \\
\hline$O C$ & 1,58 & 1,00 & 1,32 & 6,13 & 0,415 \\
\hline$M C$ & 1,11 & 0,76 & 1,00 & 2,45 & 0,262 \\
\hline$D$ & 0,46 & 0,16 & 0,41 & 1,00 & 0,093 \\
\hline
\end{tabular}

$C R=0,017$

Table 5 Local weights and pairwise comparison matrix of quality sub-

\begin{tabular}{|c|c|c|c|c|}
\hline$Q$ sub-criteria & $S R$ & $R$ & $P C$ & Weights \\
\hline SR & 1,00 & 0,27 & 0,25 & 0,116 \\
\hline R & 3,64 & 1,00 & 1,00 & 0,436 \\
\hline PC & 3,96 & 1,00 & 1,00 & 0,448 \\
\hline
\end{tabular}

$C R=0,000$

Table 6 Local weights and pairwise comparison matrix of flexibility sub-criteria

\begin{tabular}{|c|c|c|c|}
\hline$F$ sub-criteria & $S R$ & $R$ & Weights \\
\hline SR & 1,00 & 1,37 & 0,578 \\
\hline R & 0,73 & 1,00 & 0,422 \\
\hline
\end{tabular}

$C R=0,000$

Table 7 Local weights and pairwise comparison matrix of performance sub-criteria

\begin{tabular}{|c|c|c|c|c|c|c|}
\hline & $S$ & $S C A$ & $C T$ & $U$ & $M R$ & Weights \\
\hline$S$ & 1,00 & 0,82 & 3,39 & 2,66 & 3,92 & 0,323 \\
\hline$S C A$ & 1,21 & 1,00 & 5,71 & 3,48 & 1,99 & 0,346 \\
\hline$C T$ & 0,30 & 0,18 & 1,00 & 1,00 & 0,25 & 0,071 \\
\hline$U$ & 0,38 & 0,29 & 1,00 & 1,00 & 0,54 & 0,092 \\
\hline$M R$ & 0,26 & 0,50 & 4,07 & 1,85 & 1,00 & 0,169 \\
\hline
\end{tabular}

$C R=0,05$

Step 2: In this step, weights of the criteria were determined by assuming that they are independent from each other. The impact of each criterion to others is discussed by DMT members and the dependencies between criteria as represented at the second level in Fig. 2 are determined. It can be said in words: a) "flexibility criteria" affect "quality criteria", b) there are interdependencies between the others. According to the interdependencies, four pairwise comparison matrices were built for $C, Q, F$ and $P$ criteria and relative weights are calculated as listed in Tab. 8. "0" values in Tab. 8 shows no relation between two criteria while numeric values show the impact between two criteria. Great value refers to the strength of the impact. For example, the $C$ 's value of relative impact for $Q$ is 0,144 .

Table 8 Degree of relative impact for criteria

\begin{tabular}{|c|c|c|c|c|}
\hline & $C$ & $Q$ & $F$ & $P$ \\
\hline$C$ & 0,000 & 0,144 & 0,329 & 0,120 \\
\hline$Q$ & 0,588 & 0,000 & 0,000 & 0,690 \\
\hline$F$ & 0,144 & 0,190 & 0,000 & 0,191 \\
\hline$P$ & 0,268 & 0,665 & 0,671 & 0,000 \\
\hline
\end{tabular}

Relative importance of the criteria using the data in Tab. 3 and Tab. 8 is calculated as follows:

$$
w=\left[\begin{array}{l}
C \\
Q \\
F \\
P
\end{array}\right]=\left[\begin{array}{cccc}
0 & 0,144 & 0,329 & 0,120 \\
0,588 & 0 & 0 & 0,690 \\
0,144 & 0,190 & 0 & 0,191 \\
0,268 & 0,665 & 0,671 & 0
\end{array}\right] \times\left[\begin{array}{l}
0,128 \\
0,395 \\
0,147 \\
0,330
\end{array}\right]=\left[\begin{array}{l}
0,145 \\
0,303 \\
0,156 \\
0,396
\end{array}\right]
$$




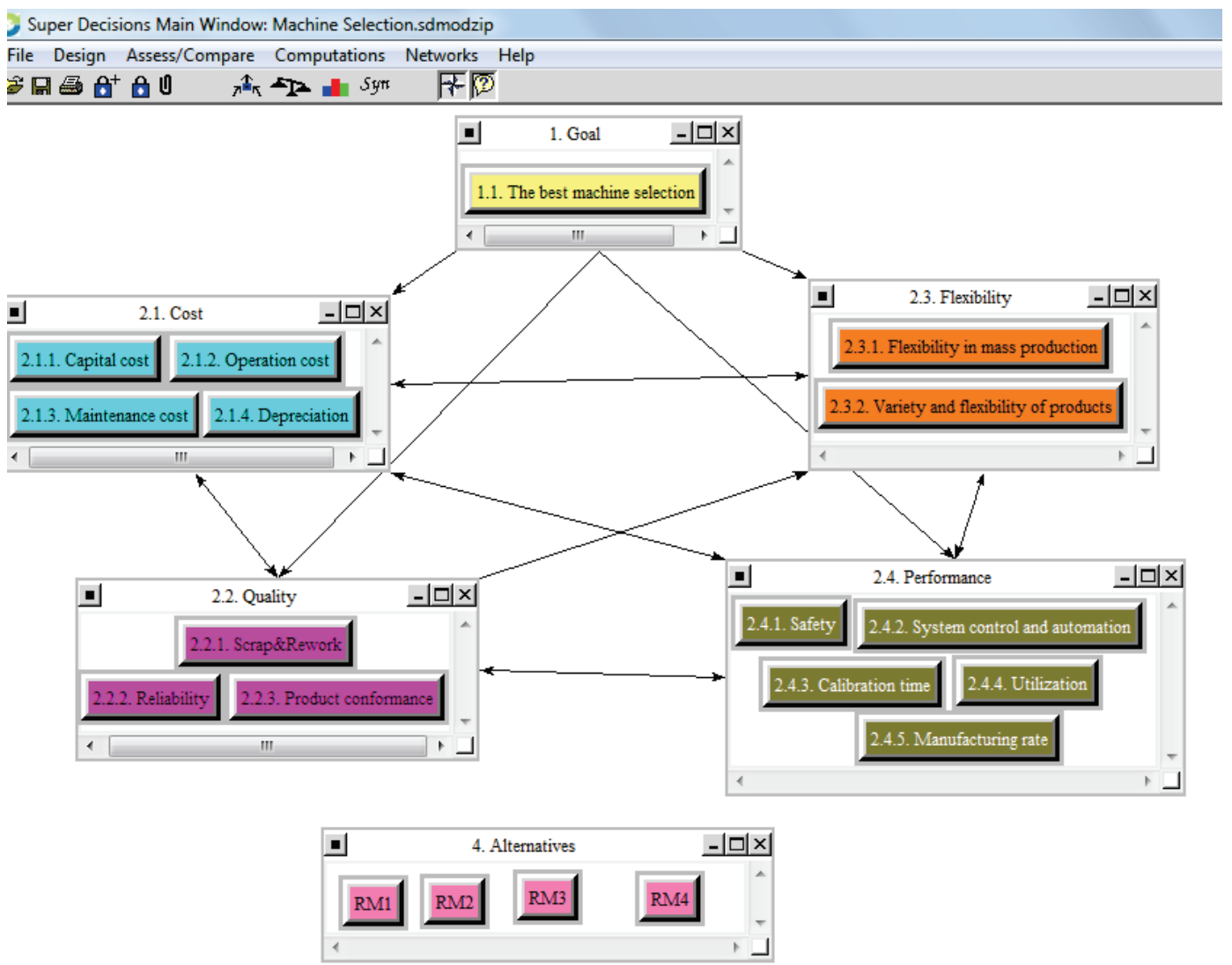

Figure 2 The network structure for the machine selection problem

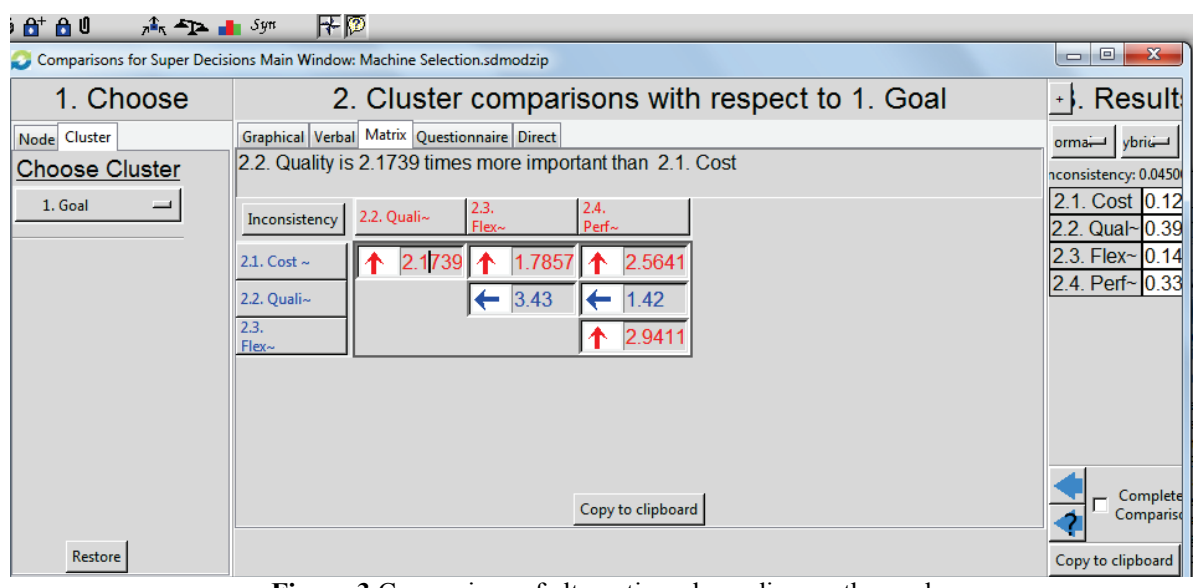

Figure 3 Comparison of alternatives depending on the goal

According to the calculations, the criterion " $P$ " is the most important criterion to be able to select the most appropriate machine. It can be easily seen from Tab. 3 that the weights of the criteria change according to the consideration of dependence and inter-dependence. For example, the results based on inter-dependences among criteria change from 0,128 to 0,$145 ; 0,395$ to 0,$303 ; 0,147$ to 0,156 and 0,330 to 0,396 for the weight values of criteria $C, Q, F$ and $P$, respectively.

Step 3: Global weights for the sub-criteria are calculated depending on inter-dependent weights of the criteria which are calculated in Step 1 and local weights of the sub-criteria given in Tabs. $3 \div 8$. The local weight of the sub-criterion is multiplied with the inter-dependent weight of its main criterion. The result gives the subcriterion's global weight. The global weights of subcriteria are calculated and presented in Tab. 9.
Table 9 Computed global weights for sub-criteria

\begin{tabular}{|c|c|c|c|c|}
\hline $\begin{array}{c}\text { Criteria and local } \\
\text { weights }\end{array}$ & $\begin{array}{l}\text { Sub- } \\
\text { criteria }\end{array}$ & Abb. & $\begin{array}{c}\text { Local } \\
\text { weights }\end{array}$ & $\begin{array}{l}\text { Global } \\
\text { weights }\end{array}$ \\
\hline \multirow{4}{*}{$C(0,145)$} & $I C$ & $\mathrm{C} 1$ & 0,23 & 0,033 \\
\hline & $R C$ & $\mathrm{C} 2$ & 0,415 & 0,06 \\
\hline & $M C$ & C3 & 0,262 & 0,038 \\
\hline & $D$ & C4 & 0,093 & 0,014 \\
\hline \multirow{3}{*}{$Q(0,303)$} & $S R$ & $\mathrm{C} 5$ & 0,116 & 0,035 \\
\hline & $R$ & C6 & 0,436 & 0,132 \\
\hline & $P C$ & $\mathrm{C} 7$ & 0,448 & 0,136 \\
\hline \multirow{2}{*}{$F(0,156)$} & $F M P$ & C8 & 0,578 & 0,09 \\
\hline & $V F P$ & C9 & 0,422 & 0,066 \\
\hline \multirow{5}{*}{$P(0,396)$} & $S$ & $\mathrm{C} 10$ & 0,323 & 0,128 \\
\hline & $S C A$ & $\mathrm{C} 11$ & 0,346 & 0,137 \\
\hline & $C T$ & C12 & 0,071 & 0,028 \\
\hline & $U$ & C13 & 0,092 & 0,036 \\
\hline & $M R$ & C14 & 0,169 & 0,067 \\
\hline
\end{tabular}


According to the global sub-criteria weights, presented in Tab. 9, the three most important sub-criteria to machine selection are "SCA - System control and automation", "PC - Product conformance" and "R Reliability". The values of $C R$ for the pairwise comparison matrices are computed as $\forall C R<0,1$. Thus, the pairwise comparisons are consistent and the criteria's weights can be used in the proposed approach.

\subsection{GRA calculations}

Alternative RMs are evaluated according to the fourteen criteria in this stage. Numerical values are used for quantitative criteria such as capital cost. However, DMT members need to use linguistic terms to evaluate alternatives according to the qualitative criteria such as product conformance, safety, system control and automation, etc. The linguistic terms used to present five situations of performance are very poor $(V P=0,1)$, poor $(P=0,3)$, moderate $(M=0,5)$, good $(G=0,7)$, excellent $(E=0,9)[46,47]$. The performance values of alternative RMs based on the criteria are shown in Tab. 10.

Some data in Tab. 10 such as capital are hundreds of times greater than others (e.g. reliability, utilization, etc.). The data are normalized using Eq. (4) and (5) for largeris-better criteria and smaller-is-better criteria, respectively. $\mathrm{C} 1, \mathrm{C} 2, \mathrm{C} 3, \mathrm{C} 4, \mathrm{C} 5$ and $\mathrm{C} 12$ are "smaller is better" criteria and the others are "bigger the better" criteria. Microsoft Excel is used for all the calculations and the calculations for $x_{1}^{*}, x_{2}^{*}$ by using Eq. (4) or (5) are shown below and the normalized data are shown in Tab. 11.

$$
\begin{aligned}
& x_{1}^{*}(1)=\frac{42000-42000}{42000-38500}=0 \quad x_{1}^{*}(2)=\frac{0,9-0,3}{0,9-0,3}=1 \\
& x_{1}^{*}(7)=\frac{0,5-0,3}{0,7-0,3}=0,5
\end{aligned}
$$

The resulting GRCs $\gamma_{o i}(j)$ are computed by using Eq. (2). In the study, the distinguished coefficient was fixed as 0,5 . For example:

$$
\begin{aligned}
& \gamma_{o 1}(1)=\frac{0+0,5 \cdot 1}{1+0,5 \cdot 1}=0,33 \quad \gamma_{o 1}(2)=\frac{0+0,5 \cdot 1}{0+0,5 \cdot 1}=1 \\
& \gamma_{o 1}(7)=\frac{0+0,5 \cdot 1}{0,5+0,5 \cdot 1}=0,5
\end{aligned}
$$

The calculation results are given in Tab. 12 .

The last step is to calculate the GRG $\Gamma_{o i}$ by using Eq. (3). The grey relational vector can be calculated by multiplying GRC matrix in Tab. 12 by the weighting vector in Tab. 9. According to GRA, the alternative with the higher GRG is the better alternative [47]. Some examples are shown below, other results are given in Tab. 13. As indicated in Tab. 13, four alternative machines, RM1, RM2, RM3 and RM4, are ranked 3, 4, 1 and 2, respectively.

$$
\begin{aligned}
& \Gamma_{o 1}\left(R M_{1}\right)=[0,033 \cdot 0,011+0,06 \cdot 0,06+\ldots+0,067 \cdot 0,034]=0,607 \\
& \Gamma_{o 3}\left(R M_{3}\right)=[0,033 \cdot 0,014+0,06 \cdot 0,02+\ldots+0,067 \cdot 0,022]=0,711
\end{aligned}
$$

Table 10 Evaluation matrix for router machine selection

\begin{tabular}{|l|c|c|c|c|c|c|c|c|c|c|c|c|c|c|}
\hline & C1 & C2 & C3 & C4 & C5 & C6 & C7 & C8 & C9 & C10 & C11 & C12 & C13 & C14 \\
\hline RM1 & 42000 & 0,3 & 0,7 & 0,7 & 0,7 & 0,7 & 0,5 & 0,9 & 0,9 & 0,9 & 0,5 & 0,7 & 0,7 & 0,7 \\
\hline RM2 & 38500 & 0,3 & 0,5 & 0,7 & 0,5 & 0,7 & 0,3 & 0,7 & 0,9 & 0,7 & 0,7 & 0,5 & 0,5 & 0,7 \\
\hline RM3 & 41000 & 0,9 & 0,7 & 0,3 & 0,1 & 0,9 & 0,7 & 0,9 & 0,5 & 0,9 & 0,5 & 0,9 & 0,9 & 0,5 \\
\hline RM4 & 40000 & 0,7 & 0,5 & 0,1 & 0,3 & 0,7 & 0,5 & 0,7 & 0,7 & 0,9 & 0,7 & 0,7 & 0,9 & 0,9 \\
\hline
\end{tabular}

\begin{tabular}{|c|c|c|c|c|c|c|c|c|c|c|c|c|c|c|}
\hline RM1 & 0,011 & 0,06 & 0,013 & 0,005 & 0,012 & 0,044 & 0,068 & 0,09 & 0,066 & 0,128 & 0,046 & 0,014 & 0,018 & 0,034 \\
\hline RM2 & 033 & 0,06 & 0,038 & 0,005 & 0,015 & 0,044 & 0,045 & 0,03 & 0,066 & 43 & 137 & 0,028 & 2 & 0,034 \\
\hline RM3 & 017 & 0,02 & 0,0 & 0008 & & 32 & & 0, & & & & & & 0,022 \\
\hline RM4 & 0,018 & 0,026 & 0,038 & 0,014 & 0,021 & 0,044 & 0,068 & 0,03 & 0,033 & 0,128 & 0,137 & 0,014 & 0,036 & 0,067 \\
\hline
\end{tabular}

Table 11 Normalized data of original data

\begin{tabular}{|c|c|c|c|c|c|c|c|c|c|c|c|c|c|c|}
\hline & C1 & C2 & C3 & C4 & C5 & C6 & C7 & C8 & C9 & C10 & C11 & C12 & C13 & C14 \\
\hline RM1 & 0 & 1 & 0 & 0 & 0 & 0 & 0,5 & 1 & 1 & 1 & 0 & 0,5 & 0,5 & 0,5 \\
\hline RM2 & 1 & 1 & 1 & 0 & 0,33 & 0 & 0 & 0 & 1 & 0 & 1 & 1 & 0 & 0,5 \\
\hline RM3 & 0,29 & 0 & 0 & 0,67 & 1 & 1 & 1 & 1 & 0 & 1 & 0 & 0 & 1 & 0 \\
\hline RM4 & 0,57 & 0,33 & 1 & 1 & 0,67 & 0 & 0,5 & 0 & 0,5 & 1 & 1 & 0,5 & 1 & 1 \\
\hline
\end{tabular}

Table 12 Computed GRCs

\begin{tabular}{|c|c|c|c|c|c|c|c|c|c|c|c|c|c|c|}
\hline & C1 & C2 & C3 & C4 & C5 & C6 & C7 & C8 & C9 & C10 & C11 & C12 & C13 & C14 \\
\hline RM1 & 0,33 & 1 & 0,33 & 0,33 & 0,33 & 0,33 & 0,5 & 1 & 1 & 1 & 0,33 & 0,5 & 0,5 & 0,5 \\
\hline RM2 & 1 & 1 & 1 & 0,33 & 0,43 & 0,33 & 0,33 & 0,33 & 1 & 0,33 & 1 & 1 & 0,33 & 0,5 \\
\hline RM3 & 0,41 & 0,33 & 0,33 & 0,6 & 1 & 1 & 1 & 1 & 0,33 & 1 & 0,33 & 0,33 & 1 & 0,33 \\
\hline RM4 & 0,54 & 0,43 & 1 & 1 & 0,6 & 0,33 & 0,5 & 0,33 & 0,5 & 1 & 1 & 0,5 & 1 & 1 \\
\hline
\end{tabular}

Table 13 Computed GRGs

According to the ANP and GRA computations, it is decided to purchase RM-3. How the criteria weights will affect the ranking is analysed. From the result of ANP calculation, it is clear that system control and automation (criterion 11) and product conformance (criterion 7) have the most important impact on the final ranking. RM3 is the first preferred one according to hybrid methods (ANPGRA and ANP-TOPSIS) as shown in Tab. 14. RM4, 
RM1 and RM2 are ranked, respectively. On the other hand, RM4 is the best one with the computation of GRA or TOPSIS method. The results indicate the importance of criteria weights for decision making problems. That is the reason why a hybrid algorithm is preferred in the study. Criteria weights can be different for particular problems or other DMs. In this study, a model is proposed that can be easily modified for various criteria weights or machine selection problems.

Table 14 Alternatives' ranks based on different methods

\begin{tabular}{|c|c|c|c|c|c|c|c|c|}
\hline & \multicolumn{2}{|c|}{ ANP-GRA } & \multicolumn{2}{c|}{ GRA } & \multicolumn{2}{c|}{$\begin{array}{c}\text { ANP- } \\
\text { TOPSIS }\end{array}$} & \multicolumn{2}{c|}{ TOPSIS } \\
\hline Alt. & Sum & Rank & Sum & Rank & $C i^{*}$ & Rank & $C i^{*}$ & Rank \\
\hline RM1 & 0,607 & 3 & 0,571 & 4 & 0,504 & 3 & 0,406 & 4 \\
\hline RM2 & 0,589 & 4 & 0,638 & 3 & 0,409 & 4 & 0,412 & 3 \\
\hline RM3 & 0,711 & 1 & 0,644 & 2 & 0,584 & 1 & 0,580 & 2 \\
\hline RM4 & 0,673 & 2 & 0,695 & 1 & 0,545 & 2 & 0,641 & 1 \\
\hline
\end{tabular}

\subsection{Sensitivity Analysis}

Sensitivity analysis is performed to show the effect of the handled variable on the other variables. A sensitivity analysis is performed to show the effect of the criterion (C11) weight on other criteria weights. The criterion "system control and automation (C11)" is the most important criterion for machine selection problem and it is analyzed. Assessment of sensitivity is made by changing weight of the handled criterion at a certain percent change $(P C)$ level. Weight of the criterion that is considered for sensitivity analysis is calculated by the given formula [48]:

$$
\begin{aligned}
& w_{i}=w_{i 0}+w_{i 0} \cdot P C \\
& w_{j}=\left(1-w_{i}\right) \cdot \frac{w_{j 0}}{\left(1-w_{i 0}\right)}
\end{aligned}
$$

In this formula, variable $w_{i}$ is used for calculating the weight of criterion that is taken into consideration for the sensitivity analysis and variable $w_{j}$ is used to obtain the weight of the other criteria. Sensitivity analysis is made for percent weight change values of $-0,1 ;-0,05 ; 0 ; 0,05$; 0,1. By using Eq. (9) and Eq. (10), weight of each criterion in each scenario is calculated and presented in Tab. 15. Different criteria weights can cause changes on ranking of alternatives. The proposed model also can be used for different decision making problems.

Table 15 Calculated weights of each criterion with respect to weight change ratio

\begin{tabular}{|c|c|c|c|c|c|c|c|c|c|c|c|c|c|c|}
\hline Change & C1 & C2 & C3 & C4 & C5 & C6 & C7 & C8 & C9 & C10 & C11 & C12 & C13 & C14 \\
\hline$-0,100$ & 0,034 & 0,061 & 0,039 & 0,014 & 0,036 & 0,134 & 0,138 & 0,092 & 0,067 & 0,130 & 0,123 & 0,029 & 0,037 & 0,068 \\
\hline$-0,050$ & 0,034 & 0,061 & 0,038 & 0,014 & 0,035 & 0,133 & 0,137 & 0,091 & 0,067 & 0,129 & 0,130 & 0,028 & 0,037 & 0,067 \\
\hline 0,000 & 0,033 & 0,060 & 0,038 & 0,014 & 0,035 & 0,132 & 0,136 & 0,090 & 0,066 & 0,128 & 0,137 & 0,028 & 0,036 & 0,067 \\
\hline 0,050 & 0,033 & 0,060 & 0,038 & 0,013 & 0,035 & 0,131 & 0,135 & 0,090 & 0,066 & 0,127 & 0,144 & 0,028 & 0,036 & 0,066 \\
\hline 0,100 & 0,033 & 0,059 & 0,037 & 0,013 & 0,035 & 0,130 & 0,133 & 0,089 & 0,065 & 0,126 & 0,151 & 0,028 & 0,036 & 0,066 \\
\hline
\end{tabular}

\section{Conclusions}

In this study, a decision model which can be easily used to rank alternatives based on their performance according to the determined criteria is proposed. The approach is particularly a support to decide correctly while information about performance values of alternatives is missing. The ANP method is used to determine the weights of criteria while the GRA method is used for ranking of alternatives. Additionally, two different rankings based on criteria weights and not on criteria weights are computed, the necessity of the ANP method in the decision approach is shown. The proposed approach is different from the other studies in machine selection literature depending on its structure using the ANP and GRA methods. The superiority of the approach to the other methods is explained as follows. The ANPGRA integrated method is well suited to deal with multicriteria decisions that involve both qualitative and quantitative criteria. Despite the fact that all the calculations in the proposed model can be performed by using software like "Super Decision", they were conducted using Microsoft Excel which can be applied easily by anybody (technical staff, managers, manufacturer, vendor, etc.) familiar with basic Microsoft knowledge. The proposed approach has only been implemented on a machine selection problem within the immediate company; however, company management has declared the proposed model satisfactory and implemental for similar problems within other companies. In addition, other MCDM methods such as Data Envelope Analysis (DEA), Decision Making and Trial Evaluation Laboratory (DEMATEL), Multi-attribute Utility Method (MAUT) and Preference ranking organization method for enrichment evaluations (PPROMETHEE) can be used to evaluate multiple attributes. Whether these methods can be applied to solve the same problem, differences and similarities in the ranking can be discussed. This will improve the proposed model and be a good topic for upcoming studies.

\section{References}

[1] Ayag, Z.; Ozdemir, R. G. A fuzzy AHP approach to evaluating machine tool alternatives. // Journal of Intelligent Manufacturing. 17, (2006), pp. 179-190.

[2] Chan, F. T. S.; Ip, R. W. L.; Lau, H. Integration of expert system with analytic hierarchy process for the design of material handling equipment selection system. // Journal of Materials Processing Technology. 116, (2011), pp. 137145. DOI: 10.1016/S0924-0136(01)01038-X

[3] Kulak, O.; Durmusoglu, M. B.; Kahraman, C. Fuzzy multiattribute equipment selection based on information axiom. // Journal of Materials Processing Technology. 169, (2005), pp. 337-345. DOI: 10.1016/j.jmatprotec.2005.03.030

[4] Standing, G.; Flores, B.; Olson, D. Understanding managerial preferences in selection equipment. // Journal of Operation Management. 19, (2001), pp. 23-37. DOl: 10.1016/S0272-6963(00)00047-4

[5] Geetha, K.; Ravindran, D.; Siva Kumar, M.; Islam, M. N. Multi-objective optimization for optimum tolerance synthesis with process and machine selection using a 
genetic algorithm. // The International Journal of Advanced Manufacturing Technology. 67, 9-12(2013), pp. 2439-2457. DOI: 10.1007/s00170-012-4662-6

[6] Wang, T. Y.; Shaw, C. F.; Chen, Y. L. Machine selection in flexible manufacturing cell, a fuzzy multiple attribute decision making approach. // International Journal of Production Research. 38, (2000), pp. 2079-2097. DOl: 10.1080/002075400188519

[7] Beaulieu, A.; Gharbi, A.; Kadi, A. An algorithm for the cell formation and the machine selection problems in the design of a cellular manufacturing system. // International Journal of Production Research. 35(1997), pp 1857-1874. DOl: 10.1080/002075497194958

[8] Rouyendegh, B. D.; Baç, U.; Erkan, T. R. Sector selection for ERP implementation to achieve most impact on supply chain performance by using AHP-TOPSIS hybrid method // Technical Gazette. 21, 5(2014), pp. 933-937.

[9] Paramasivam, V.; Senthil, V.; Ramasamy, N. R. Decision making in equipment selection, an integrated approach with digraph and matrix approach, AHP and ANP. // International Journal of Advanced Manufacturing Technology. 54, 9-12(2011), pp. 1233-1244.

[10] Yildız, A. R. Hybrid Taguchi-Harmony Search Algorithm for Solving Engineering Optimization Problems. // International Journal of Industrial Engineering: Theory, Applications and Practice. 15, 3(2008), pp. 286-293.

[11] Tuzkaya, G.; Gulsun, B.; Kahraman, C.; Ozgen, D. An integrated fuzzy multi-criteria decision making methodology for material handling equipment selection problem and an application. // Expert Systems with Applications. 37(2010), pp. 2853-2863. DOI 10.1016/j.eswa.2009.09.004

[12] Begicevic, N.; Divjak, B.; Hunjak, T. Decision-making on prioritization of projects in higher education institutions using the analytic network process approach. // Central European Journal of Operations Research. 18(2010), pp. 341-364. DOI: 10.1007/s10100-009-0113-3

[13] Zeleny, M. Multiple Criteria Decision Making. McGrawHill, New York, 1982.

[14] Vincke, P. Multicriteria Decision Aid, Wiley, 1992.

[15] Haq, A. N.; Kannan, G. An integrated approach for selecting a vendor using grey relational analysis. // International Journal of Information Technology \& Decision Making. 5, 2(2006), pp. 277-295. DOI: 10.1142/S0219622006001952

[16] Su, Z. X. A hybrid fuzzy approach to fuzzy multi-attribute group decision-making. // International Journal of Information Technology \& Decision Making. 10, 4(2011), pp. 695-711. DOI: 10.1142/S021962201100452X

[17] Deng, J. L. Grey System Fundamental Method. Huazhong University of Science and Technology, Wuhan, China, 1982.

[18] Klir, G. J.; Folger, T. A. Fuzzy Sets, Uncertainty, and Information. Prentice Hall, Englewood Cliffs, New Jersey, 1988

[19] Li, P.; Tan, T. C.; Lee, J. Y. Grey relational analysis of amine inhibition of mild steel corrosion in acids. // Corrosion. 53, (1997), pp. 186-194. DOI: 10.5006/1.3280459

[20] Saaty, T.L. Decision making with dependence and feedback, The analytic network process. Pittsburgh, RWS Publications, 1996.

[21] Liang, C.; Li, Q. Enterprise information system project selection with regard to BOCR. // International Journal of Project Management. 26, 8(2007), pp. 810-820. DOI: 10.1016/j.jproman.2007.11.001

[22] Meade, L. M.; Sarkis, J. Analyzing organizational project alternatives for agile manufacturing processes, an analytical network approach. // International Journal of Production Research. 37, (1999), pp. 241-261. DOI $10.1080 / 002075499191751$
[23] Meade, L. M.; Presley, A. R\&D project selection using the analytic network process. // IEEE Transactions on Engineering Management. 49, (2002), pp. 59-66. DOI: 10.1109/17.985748

[24] Lee, J. W.; Kim, S. H. Using analytic network process and goal programming for interdependent information system project selection. // Computers and Operations Research. 27, (2000), pp. 367-382. DOI: 10.1016/S0305-0548(99)00057$\mathrm{X}$

[25] Karsak， E. E.; Sozer，S.; Alptekin，S. E. Production planning in quality function deployment using a combined analytical network process and goal programming approach. // Computers and Industrial Engineering. 44, (2002), pp. 171-190. DOI: 10.1016/S0360-8352(02)00191-2

[26] Partovi, F. Y.; Corredoira, R. A. Quality function deployment for the good of soccer. // European Journal of Operational Research. 137, (2002), pp. 642-656. DOI: 10.1016/S0377-2217(01)00072-8

[27] Wu, Y. W.; Sukoco, B. D.; Li, C. Y.; Chen, S. H. An integrated multi-objective decision-making process for supplier selection with bundling problem. // Expert Systems with Applications. 36, 2(2009), pp. 2327-2337. DOI: 10.1016/j.eswa.2007.12.022

[28] Kabak, M. A Fuzzy DEMATEL-ANP Based Multi Criteria Decision Making Approach to Personnel Selection. // Journal of Multiple Valued Logic and Soft Computing. 20, (2013), pp. 571-593.

[29] Dağdeviren, M.; Yüksel, İ.; Kurt, M. A fuzzy analytic network process (ANP) model to identify faulty behaviors risk (FBR) in work systems. // Safety Sciences. 34, (2008), pp. 96-107. DOI: 10.1016/j.ssci.2007.02.002

[30] Kabak, M.; Köse, E.; Kırılmaz, O.; Burmaoğlu, S. A fuzzy multi-criteria decision making approach to assess building energy performance. // Energy and Buildings. 72, (2014), pp. 382-389. DOI: 10.1016/j.enbuild.2013.12.059

[31] Yazgan, H. R.; Boran, S.; Göztepe, K. Selection of dispatching rules in FMS, ANP model based on BOCR with choquet integral. // International Journal of Advanced Manufacturing Technology. 49, 5-8(2010), pp. 785-801.

[32] Chih, C. C. Check quality of recycled building materials via GRA and AHP. // The Journal of Grey System. 1, (2010), pp. 63-72.

[33] Li, G. D.; Yamaguchi, D.; Nagai, M. A grey-based decision-making approach to the supplier selection problem. // Mathematical and Computer Modeling. 46, (2007), pp. 573-581. DOI: 10.1016/j.mcm.2006.11.021

[34] Huang K. Y.; Jane, C. J. A hybrid model for stock market forecasting and portfolio selection based on ARX, grey system and RS theories. // Expert Systems with Applications. 36, 3(2009), pp. 5387-5392. DOI: 10.1016/j.eswa.2008.06.103

[35] Tsai, L. C.; Shan, C. Y. Evaluating the emerging industry credit ability for banking sector using AHP and GRA, A case study in Taiwanese solar energy industry. // The Journal of Grey System. 4, (2008), pp. 359-374.

[36] Tai, Y. Y.; Lin, J. Y.; Chen, M. S.; Lin, M. C. A grey decision and prediction model for investment in the core competitiveness of product development. // Technological Forecasting \& Social Change. 78, (2011), pp. 1254-1267. DOI: 10.1016/j.techfore.2011.03.004

[37] Jianxin, O.; Tian, X. Grey evaluation of stock quality. // The Journal of Grey System. 4, (2005), pp. 371-376.

[38] Yang, C. C.; Chen, B. S. Supplier selection using combined analytical hierarchy process and grey relational analysis. // Journal of Manufacturing Technology Management. 17, 7(2006), pp. 926-941. DOI: 10.1108/17410380610688241

[39] Wang, H.; Chun, L.; Yang, J. On demand data broadcast scheduling based on AHP and GRA methods in wireless broadcast/UMTS integrated systems. // The Journal of 
China Universities of Posts and Telecommunications. 14, 4(2007), pp. 1-6. DOI: 10.1016/S1005-8885(08)60029-1

[40] Lin, C. T.; Chang, C. W.; Chen, C. B. A simple approach to solving multi-response quality characteristic problems in CMOS ion implantation. // International Journal of Advanced Manufacturing Technology. 28, 5-6(2006), pp. 592-595. DOI: 10.1007/s00170-004-2396-9

[41] Hsia, K. H.; Wu, J. H. A study on the data preprocessing in grey relational analysis. // Journal of Chinese Grey System. 1, (1997), pp. 47-53.

[42] Ravindran, A. R.; Bilsel, R. U.; Wadhwa, V.; Yang, T. Risk adjusted multicriteria supplier selection models with applications. // International Journal of Production Research. 48, 2(2010), pp. 405-424. DOI: 10.1080/00207540903174940

[43] Labib, A. W. A supplier selection model: a comparison of fuzzy logic and the analytic hierarchy process. // International Journal of Production Research. 49, 21(2011), pp. 6287-6299. DOI: 10.1080/00207543.2010.531776

[44] Maniya, K. D.; Bhatt, M. G., A multi-attribute selection of automated guided vehicle using the AHP/M-GRA technique. // International Journal of Production Research. 49, 20(2011), pp. 6107-6124. DOl: $10.1080 / 00207543.2010 .518988$

[45] Sevkli, M. An application of the fuzzy ELECTRE method for supplier selection. // International Journal of Production Research. 48, 12(2010), pp. 3393-3405. DOl: 10.1080/00207540902814355

[46] Ling, M.; Hang, S. J. The application of fuzzy decisionmaking approach in the process alternatives of municipal wastewater treatment plant. // Water and Wastewater Engineering. 3, (1998), pp. 6-9.

[47] Zeng, G.; Jiang, R.; Huang, G.; Xu, M.; Li, J. Optimization of wastewater treatment alternative selection by hierarchy grey relational analysis. // Journal of Environmental Management. $\quad 82$, (2007), pp. 250-259. DOl: 10.1016/j.jenvman.2005.12.024

[48] Selcuk, L. An avalanche hazard model for Bitlis Province, Turkey, using GIS based multicriteria decision analysis. // Turkish Journal of Earth Sciences. 22, (2013), pp. 523-535. DOI: 10.3906/yer-1201-10

\section{Authors' addresses}

Mehmet Kabak, Assoc. Prof.

Department of Industrial Engineering

Gazi University, 06570, Maltepe, Ankara, Turkey

mkabak@gazi.edu.tr

Metin Dağdeviren, Prof.

Department of Industrial Engineering

Gazi University, 06570, Maltepe, Ankara, Turkey

metindag@gazi.edu.tr 